\title{
Hidden ecosystem function of rabbitfishes? Siganus fuscescens feeds on the soft coral, Sarcophyton sp.
}

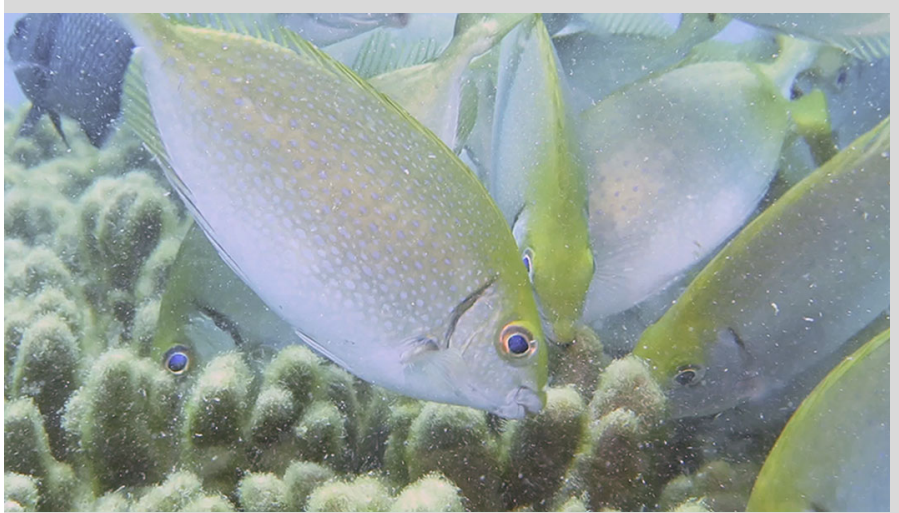

Fig. 1 Siganus fuscescens grazing on algae growing on Sinularia sp.

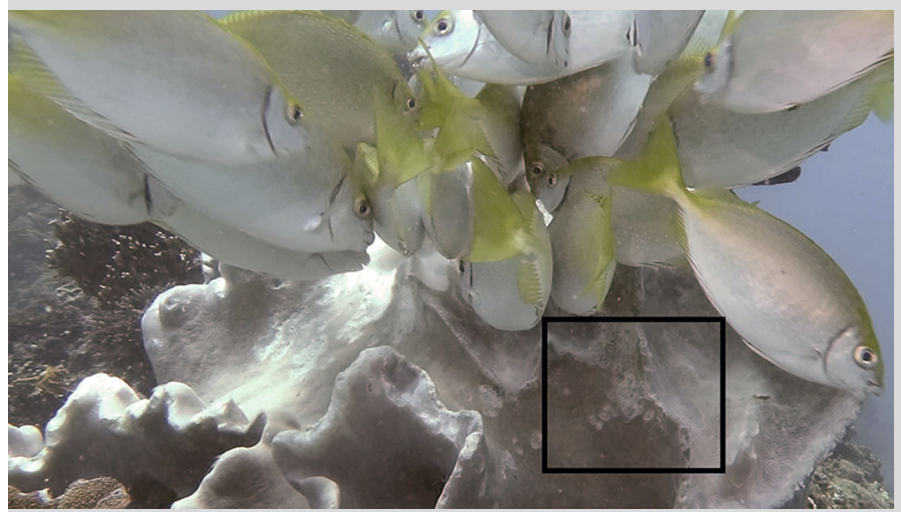

Fig. 2 Siganus fuscescens feeding on Sarcophyton sp.

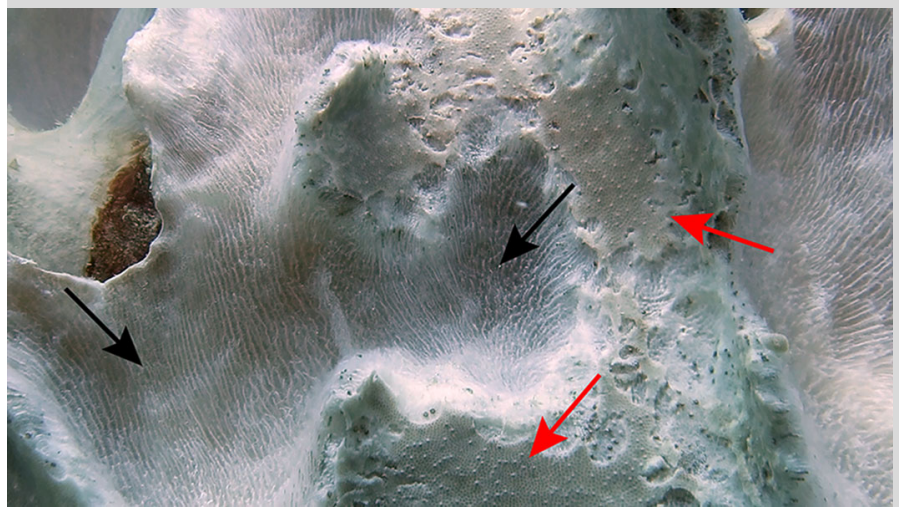

Fig. 3 Top of a colony of Sarcophyton sp. after being fed upon by a group of S. fuscescens. Black arrow: scars; Red arrow: ungrazed coral tissue
The rabbitfishes, Siganus spp., are generally classified as herbivores. A recent study shows that closely related Siganus species can express distinct ecosystem functions with one as a grazer of reef turf algae and the other primarily a grazer of off-reef detrital aggregates (Fox et al. 2009), suggesting that the herbivorous role of rabbitfishes on reefs might not be as uniform as previously thought. In August 2014, at the Hobihu Marine Protected Area (MPA), Kenting National Park $\left(21^{\circ} 56.30^{\prime} \mathrm{N} ; 120^{\circ} 44.75^{\prime} \mathrm{E}\right)$, southern Taiwan, where herbivorous fishes are dominated by Siganus fuscescens and the benthic community is composed of soft corals including Sinularia, Lobophytum, and Sarcophyton, we observed schools of S. fuscescens foraging at the tops of soft corals and grazing on turf algae growing on the coral surfaces (Fig. 1; Electronic Supplementary Materials, ESM 1). One of the $S$. fuscescens schools (ca. 35 individuals) continued to bite Sarcophyton colonies after the surface turf algae were cropped (Fig. 2; ESM 2), leaving distinct scars on coral surfaces (Fig. 3; ESM 2). Our observations indicate that chemical toxins and sclerites (van Alstyne et al. 1994) did not deter $S$. fuscescens from feeding on Sarcophyton and provide evidence that the feeding habits of some coral reef-associated fishes might be oversimplified and should be validated on a speciesby-species basis (Bellwood et al. 2006; Fox et al. 2009).

\section{References}

Bellwood DR, Hughes TP, Hoey AS (2006) Sleeping functional group drive coral-reef recovery. Curr Biol 16:2434-2439

Fox RJ, Sunderland TL, Hoey AS, Bellwood DR (2009) Estimating ecosystem function: contrasting roles of closely related herbivorous rabbitfishes (Siganidae) on coral reefs. Mar Ecol Prog Ser 385:261-269

van Alstyne KL, Wylie CR, Paul VJ (1994) Antipredator defenses in tropical Pacific soft corals (Coelenterata: Alcyonanea). II. The relative importance of chemical and structural defenses in three species of Sinularia. J Exp Mar Bio Ecol 178:17-34

Electronic supplementary material The online version of this article (doi:10.1007/s00338-014-1250-2) contains supplementary material, which is available to authorized users.

F.-W. Kuo - T.-Y. Fan · M.-C. Liu

National Museum of Marine Biology and Aquarium (NMMBA),

Pingtung 944, Taiwan

\section{C.-Y. Kuo}

ARC Centre of Excellence for Coral Reef Studies, James Cook

University, Townsville, QLD 4811, Australia

\section{A. Chen $(\bowtie)$}

Biodiversity Research Centre, Academia Sinica, Nangang, Taipei 115,

Taiwan

e-mail: cac@gate.sinica.edu.tw 